\title{
Laphamite, an arsenic selenide analogue of orpiment, from burning anthracite deposits in Pennsylvania
}

\author{
Pete J. Dunn \\ Department of Mineral Sciences, Smithsonian Institution, Washington, DC 20560 \\ DONALD R. PEACOR \\ Department of Geological Sciences, University of Michigan, Ann Arbor, Michigan 48109 \\ Alan J. Criddle \\ Department of Mineralogy, British Museum (Natural History), London, England, SW7 5BD \\ AND \\ ROBERT B. FINKELMAN
}

Exxon Production Research Company, PO Box 2189, Houston, Texas 77001

\begin{abstract}
ABST R ACT. Laphamite, ideally $\mathrm{As}_{2}(\mathrm{Se}, \mathrm{S})_{3}$, is monoclinic, $P 2_{1} / n$, with $a=11.86(1), b=9.756(9), c=4.265(9) \AA, \beta=$ $90.17^{\circ}, V=493.5 \AA^{3}, Z=4, D$ (calc.) $=4.60, D$ (meas.) $=$ $4.5(1) \mathrm{g} / \mathrm{cm}^{3}$. Microprobe analysis yielded: As 47.0 , Se $43.7, \mathrm{~S} 8.7$, sum $=99.4 \mathrm{wt} \%$. In plane polarized light in polished section at about $3200 \mathrm{~K}$ laphamite is moderately bireflectant from white to grey. Reflection pleochroism is absent but fiery red internal reflections are characteristic as are golden yellow reflections along scratches. Anisotropy is moderate with grey rotation tints, masked in some sections by internal reflections. Reflectance spectra in air and oil between 400 and $700 \mathrm{~nm}$ are given. Colour values for the CIE illiminant $\mathrm{C}$ in air are, for $R_{1}$ followed by $R_{2}: Y \% 29.0,33.5, \lambda_{\mathrm{d}} 480,478 ; P_{\mathrm{e}} \% 9.1,8.7$. Laphamite forms dark red crystals, up to $5.0 \mathrm{~mm}$, associated with orpiment, arsenolite, and an unnamed phase, $\mathrm{NH}_{4} \mathrm{AlF}_{4}$, in a burning coal waste-dump at Burnside, Northumberland County, Pennsylvania.
\end{abstract}

KEYWORDS: laphamite, new mineral, orpiment, Burnside, Pennsylvania.

SECONDAR Y minerals formed as a result of burning coal seams or coal waste-dumps have been found in various parts of Pennsylvania, and in other places, for many years. The mineralogy of some of these occurrences was described in detail by Lapham et al. (1980) and a new mineral, downeyite, tetragonal $\mathrm{SeO}_{2}$, was described from such burning waste-dumps by Finkelman and Mrose (1977). Our investigation of a sample from dumps at Burnside, Pennsylvania, has resulted in

(C) Copyright the Mineralogical Society the description of another new mineral, $\mathrm{As}_{2}(\mathrm{Se}, \mathrm{S})_{3}$. We have named this new mineral laphamite in honour of the late Dr Davis M. Lapham (1931-74), former Chief Mineralogist of the Pennsylvania Geological Survey (Socolow, 1976). This is a fitting phase to name for Dr Lapham inasmuch as he helped to initiate the study of the mineralogy of these coal dumps, and was particularly interested in the mineralogy of selenium (Barnes and Lapham, 1972; Lapham, 1975). The new mineral and the name have been approved by the Commission on New Minerals and Mineral Names, IMA. Type material is preserved at the Smithsonian Institution under catalogue No. 163039, and at the British Museum (Natural History) in a polished mount, E.1036, BM 1984,843.

Crystallography. Laphamite was studied using single-crystal Weissenberg and precession methods, and found to be monoclinic, $P 2_{1} / n$, with unit cell parameters $a=11.86(1), b=9.756(9), c=$ 4.265(9) $\AA, \quad \beta=90.17(30)^{\circ}, \quad \mathrm{V}=493.5 \AA^{3}$, with $Z=4$. This setting of the unit cell and space group is chosen for compatibility with those of orpiment, with which laphamite is inferred to be isostructural. The unit cell parameters were refined with powder data (Table I) obtained using a $114.6 \mathrm{~mm}$ diameter Gandolfi powder camera, a polycrystalline sample, $\mathrm{Cu}-K \alpha \mathrm{X}$-radiation, and NBS $\mathrm{Si}$ as an internal standard. However, the $\beta$ angle could not be refined because reflections for which $d$ is a function of $\beta$ 


\begin{tabular}{|c|c|c|c|c|c|}
\hline$I / I_{0}$ & $d$ (obs) & $d($ Calc) & $n k I$ & $I / I_{0}$ & $d \cos s$ \\
\hline $\begin{array}{r}5 \\
70 \\
30\end{array}$ & $\begin{array}{l}7.51 \\
4.87 \\
4.02\end{array}$ & $\begin{array}{l}7.53 \\
4.88 \\
4.02 \\
4.01 \\
3.91\end{array}$ & $\begin{array}{l}110 \\
020 \\
101 \\
101 \\
011\end{array}$ & $\begin{array}{r}10 \\
1 \\
50 \\
5 \\
2\end{array}$ & $\begin{array}{l}1.751 \\
1.727 \\
1.709 \\
1.686 \\
1.598\end{array}$ \\
\hline $\begin{array}{l}10 \\
20\end{array}$ & $\begin{array}{l}3 . c 2 \\
3.10\end{array}$ & $\begin{array}{l}3.71 \\
3.71 \\
3.21 \\
3.10 \\
3.10\end{array}$ & $\begin{array}{l}111 \\
111 \\
021 \\
121 \\
121\end{array}$ & $\begin{array}{r}1 \\
1 \\
1 \\
20 \\
5\end{array}$ & $\begin{array}{l}1.571 \\
1.559 \\
1.528 \\
1.507 \\
1.485\end{array}$ \\
\hline 100 & 2.905 & $\begin{array}{l}2.904 \\
2.895 \\
2.821 \\
2.826 \\
2.783 \\
2.775\end{array}$ & $\begin{array}{l}30 \overline{1} \\
301 \\
221 \\
221 \\
311 \\
311\end{array}$ & $\begin{array}{l}2 \\
2 \\
1 \\
2 \\
5\end{array}$ & $\begin{array}{l}1.429 \\
1.474 \\
1.399 \\
1.332 \\
1.168\end{array}$ \\
\hline $\begin{array}{l}30 \\
40\end{array}$ & $\begin{array}{l}2.587 \\
2.516\end{array}$ & $\begin{array}{l}2.586 \\
2.495 \\
2.490 \\
2.512 \\
2.439\end{array}$ & $\begin{array}{l}031 \\
321 \\
321 \\
330 \\
040\end{array}$ & $\begin{array}{l}1 \\
5 \\
5 \\
1\end{array}$ & $\begin{array}{l}1.151 \\
? .139 \\
1.087 \\
1.074\end{array}$ \\
\hline $\begin{array}{l}5 \\
1 \\
5\end{array}$ & $\begin{array}{l}2.305 \\
2.255 \\
2.179\end{array}$ & $\begin{array}{l}2.365 \\
2.359 \\
2.305 \\
2.256 \\
2.181 \\
2.176\end{array}$ & $\begin{array}{l}41 \overline{1} \\
411 \\
510 \\
240 \\
421 \\
421\end{array}$ & & \\
\hline 30 & 2.138 & $\begin{array}{l}2.133 \\
2.133 \\
2.085 \\
2.039\end{array}$ & $\begin{array}{l}520 \\
002 \\
141 \\
141\end{array}$ & & \\
\hline 5 & 1.934 & $\begin{array}{l}1.927 \\
1.929 \\
1.937 \\
1.916\end{array}$ & $\begin{array}{l}122 \\
122 \\
610 \\
530\end{array}$ & & \\
\hline 2 & 1.867 & $\begin{array}{l}1.854 \\
1.865 \\
1.868\end{array}$ & $\begin{array}{l}222 \\
347 \\
341\end{array}$ & & \\
\hline 50 & 1.777 & $\begin{array}{l}1.774 \\
1.783\end{array}$ & $\begin{array}{l}051 \\
032\end{array}$ & & \\
\hline
\end{tabular}

*Some $d(C a 1 c)$ values eliminated which have weak intensities observed on ingle-cryatal photographs.

could not be indexed unambiguously. It was therefore held constant at the value determined by single-crystal methods during the refinement of other parameters.
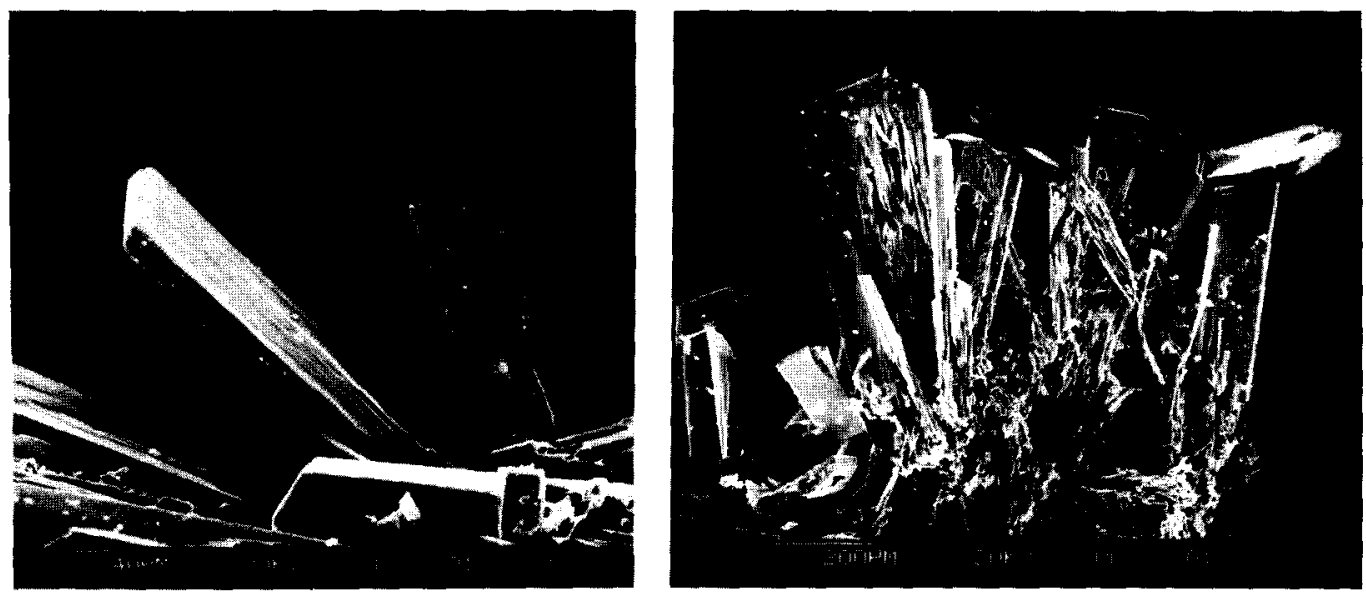

FIGS. 1 and 2. Photomicrographs of laphamite. FIG. 1 (left). Free-standing prismatic crystals. Fig. 2 (right). A cluster of
Morphologically, laphamite crystals are tabular on (010), elongate on [100], and are composed of the forms $\{100\},\{110\},\{101\}$, and $\{301\}$. Representative SEM images of laphamite crystals are presented as figs. 1 and 2. Many crystals are partially formed, or resorbed, as is common in sublimated phases.

Chemical composition. Laphamite was chemically analysed utilizing an ARL-SEMQ electron microprobe with operating conditions as follows: operating current $15 \mathrm{kV}$, sample current $0.025 \mu \mathrm{A}$, measured on brass; standards: synthetic $\mathrm{As}_{2} \mathrm{Se}_{3}$ (As,Se), synthetic CdS (S). A wavelength-dispersive microprobe scan indicated the absence of any other elements with atomic number greater than 11 , in measurable quantities. The data were corrected using a modified version of the MAGIC-4 program. The resultant analysis yielded: As 47.0, Se 43.7, S 8.7 , sum $=99.4 \mathrm{wt} . \%$. A formula, calculated on the basis of total atoms $=20$, yields: $\mathrm{As}_{8}\left(\mathrm{Se}_{7.64} \mathrm{~S}_{3.72}\right.$ $\left.\mathrm{As}_{0.64}\right)_{\Sigma 12.00}$, or $\mathrm{As}_{2}(\mathrm{Se}, \mathrm{S})_{3}$, with $\mathrm{Z}=4$. Laphamite crystals have quite variable $\mathrm{Se}: \mathrm{S}$ ratios, but in all of them Se is dominant.

Physical properties. Laphamite occurs as dark red euhedral crystals, but the colour is easily discernible only in the smallest crystals; those larger than $1.0 \mathrm{~mm}$ are very dark red and nearly opaque in visible light. Maximum crystal length is $5.0 \mathrm{~mm}$. Laphamite has a red-orange streak, resinous lustre, perfect (010) cleavage, and is extremely flexible, but not elastic. Laphamite is soft, but the hardness could not be determined quantitatively: loads of 5 , 15,25 , and $100 \mathrm{~g}$ all produced indentations that were not measurable, owing to extreme malleability of the crystals. The density, measured with a Berman balance and temperature correction, is

\footnotetext{
crystals illustrating the common habit.
} 
$4.5(1) \mathrm{g} / \mathrm{cm}^{3}$, compared with the calculated value of $4.60 \mathrm{~g} / \mathrm{cm}^{3}$.

Optical properties in reflected light. Several crystals were mounted in cold-setting epoxy resin and polished with diamond abrasives $\left(6,3,1, \frac{1}{4} \mu \mathrm{m}\right)$ on Hyprocel-Pellon laps with Engis machines. Laphamite is exceptionally difficult to polish to a scratch-free surface; only one of four crystals prepared was suitable for reflectance measurement. This was buffed, by hand, with a slurry of $\mathrm{MgO}$ in distilled water immediately before measurement.

In plane-polarized light (colour temperature about $3200 \mathrm{~K}$ ) laphamite is moderately bireflectant from white to grey and lacks reflectance pleochroism. It has strong, fiery red, internal reflections. Golden yellow internal reflections are also apparent along scratches. Between crossed polars these internal reflections mask any anisotropy on (010) sections. On (001) the anisotropy is moderate with uncoloured (greys) rotation tints. Bireflectance measurements were made using the equipment and procedure described by Criddle et al. (1983) except that $\times 8$ objectives adjusted to effective numerical apertures of 0.1 were used with a SiC (Zeiss, 472) standard. The reflectance spectra (fig. 3) show that the dispersion of the reflectance differs for the two vibration directions measured, indicating a slight difference in colour. The dispersion is unchanged in oil (Zeiss $N_{\mathrm{D}} 1.515$ ). Colour values calculated from the reflectance data (Table II) are similar for $R_{1}$ and $R_{2}$ in both media. The dominant wavelengths for the CIE A-illuminant (close to the colour temperature of the light sources used for the qualitative observations) suggest that the mineral should have a slightly bluish green hue. This would probably be

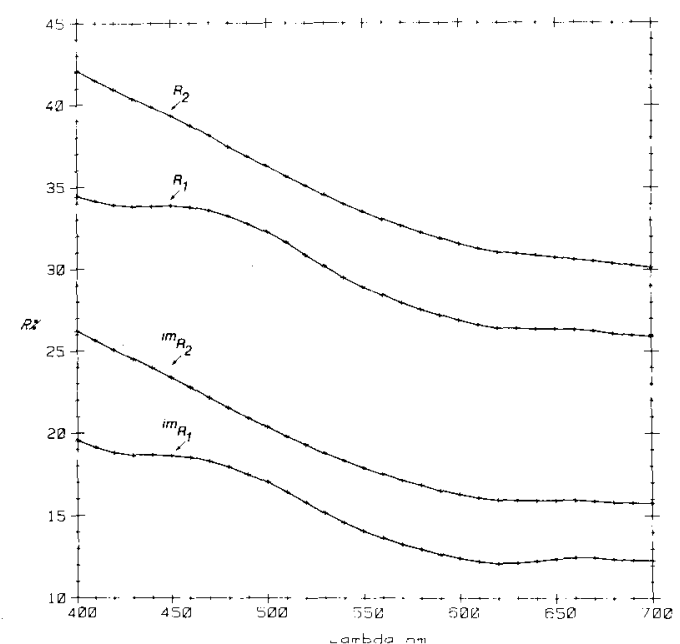

FIG. 3. Reflectance spectra in air and oil for laphamite.

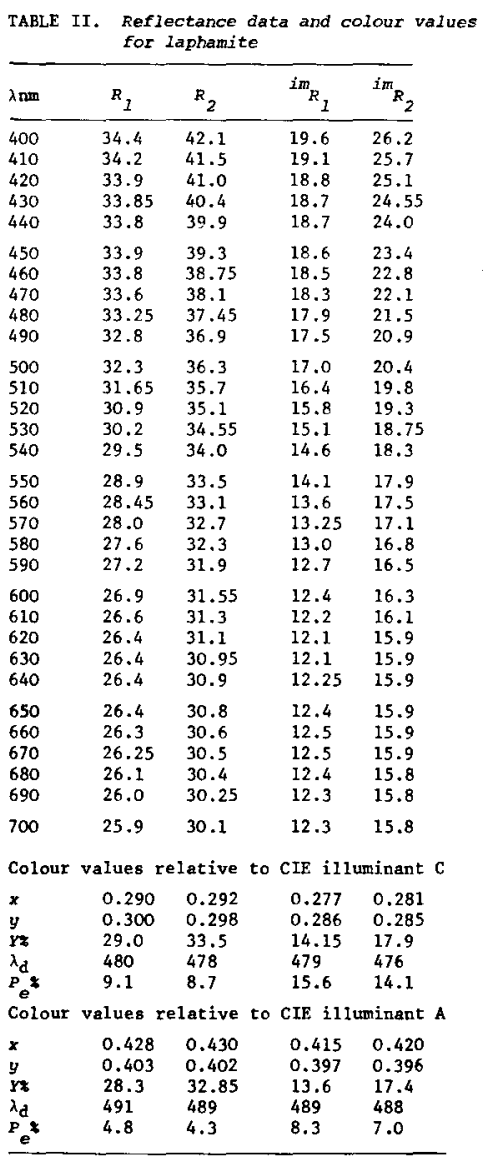

the case if the mineral were seen in association with others of similar luminance. As it is, the relative brightness of laphamite -8 to 10 times greater than the surrounding plastic-misleads the eye and the mineral is seen as uncoloured white-grey.

It was not possible to ensure that the vibration directions measured corresponded to principal sections of the crystal. For this reason, optical constants, calculated using the two-media method with the Koenigsberger equations, lack physical significance. Qualitatively, however, such calculations show that $R_{1}$ for laphamite is absorbing from 400 to $700 \mathrm{~nm}$; furthermore, that $R_{2}$ becomes transparent between 490 and $620 \mathrm{~nm}$. It follows that, in this region of the spectrum, as the reflectance is determined solely by the refractive index, the simpler Fresnel equations can be used with some confidence to derive the indices of refraction directly from the reflectances. Laphamite has an approximate $n_{590}$ of 3.6 .

Comparison of the $R$ spectra with those published for orpiment by Caye and Pasdeloup (QDF, 
1.6300, 1977), and Picot and Johan (1982, p. 283), reveal that $R_{1}$ for laphamite is similar to $R_{2}$ for orpiment, but $R_{2}$ is much higher-about $6 \%$ at $400 \mathrm{~nm}$, and $10 \%$ at $700 \mathrm{~nm}$.

Occurrence. Laphamite was discovered in a burning coal waste-dump at Burnside, Northumberland County, Pennsylvania, in the Western Middle Anthracite Field, approximately $1.5 \mathrm{~km}$ SSW of Shamokin, at $40^{\circ} 46^{\prime} 14^{\prime \prime}$ N., $76^{\circ} 34^{\prime} 12^{\prime \prime} \mathrm{W}$ It is one of the localities examined by Lapham $e t a l$. (1980) in their investigations. The specimen is a clinker, found as a surface encrustation around a single vent from which hot gases were being emitted (W. Downey, pers. comm.). Laphamite and massive, black, platy crystals (which give the X-ray powder pattern of $\mathrm{NH}_{4} \mathrm{AlF}_{4}$ ) are the dominant phases present. Octahedral crystals of arsenolite are found along the edge of some laphamite crystals. This association is illustrated in Fig. 35 of Lapham et al. (1980). Dark red amorphous gels, and a bright red soft granular aggregate which gives the powder pattern of orpiment, are also associated with laphamite. Crystals of laphamite were among the last to form, possibly by sublimation.

Acknowledgements. The writers are indebted to $\mathrm{Mr}$ Wayne Downey who found the original specimen, and to Miss Mary Mrose for counsel and guidance in the original stages of the investigation. We remain indebted to $\mathrm{Dr}$
Lapham for his insights into the mineralogy of these burning coal-dumps. We are grateful to Dr C. J. Stanley. for preparation of the polished mount of laphamite. We appreciate the assistance of Dr John S. Berkes in the early stages of this investigation.

\section{REFERENCES}

Barnes, J. H., and Lapham, D. M. (1972) Selenium Pennsylvania's rarest mineral? Penn. Geol. 3, no. 2, 8-9, Caye, R., and Pasdeloup, J. (1977) In IMA-COM Quantitative Data File (1st Issue), Ed. N. F. M. Henry.

Criddle, A. J., Stanley, C. J., Chisholm, J. E., and Fejer, E. E. (1983) Henryite, a new copper-silver telluride from Bisbee, Arizona. Bull. Mineral. 106, 511-17.

Finkelman, R. B., and Mrose, M. C. (1977) Downeyite, the first verified natural occurrence of $\mathrm{SeO}_{2} . \mathrm{Am}$. Mineral. 62, 316-20.

Lapham, D. M. (1975) Selenium in eastern Pennsylvania, a benefit or hazard? Penn. Geol. 6, no. 2, 13-16.

- Barnes, J. H., Downey, W. F., and Finkelman, R. B (1980) Mineralogy associated with burning anthracite deposits of eastern Pennsylvania. Pennsylvania Geo. logical Survey, Mineral Resources Report 78, 82 pp.

Picot, P., and Johan, Z. (1982) Atlas of ore minerals. BRGM and Elsevier, $458 \mathrm{pp}$.

Socolow, A. A. (1976) Memorial of Davis M. Lapham, May 5, 1931-December 20, 1974. Am. Mineral. 61, 528-30.

[Manuscript received 2 September 1985] 